\title{
IRRIGATION SCHEDULING ASSESSMENT FOR SNAP BEAN AND SQUASH UNDER DRIP IRRIGATION CONDITIONS IN NORTH NILE DELTA. \\ Labeeb, G. ${ }^{*}$; M.A.M. Ibrahim ${ }^{\star \star}$ and A.A. Abdel-khalek** \\ * Soils Dep.Fac. Of Agric.,Mans. Univ. Egypt \\ ${ }^{*}$ Soils, Water \& Environment Res. Inst., A. R.C., Egypt
}

\begin{abstract}
Two field experiments were carried out in Sakha Agricultural Research Station, Kafr el-Shiekh Governorate, to determine the most suitable irrigation frequencies and quantities, for Snap bean and Squash, grown under drip irrigation system. The irrigation intervals of snap bean were irrigation every 4, 8, 12 and 16 days, where the irrigation intervals of Squash were, irrigation every 2, 4, 6 and 8 days. Irrigation quantities were 0.8 and 1.0 evaporation ( Ep ), for both snap bean and squash, based on pan evaporation.

The obtained results are summarized in:

1-snap bean

Irrigation water intervals significantly affected number of pods/plant, where 4 days interval recorded the highest mean (9.7). No significant differences were found between irrigation water quantities treatment means in this trait. The highest value was obtained with the treatment of 4 days interval with irrigation water quantity of 1.0 Ep .

Irrigation intervals significantly affected pods dry weight/plant, where 4 days interval treatment mean represents $157.5 \%$ of that of 16 days interval treatment mean . Irrigation water quantities didn't significantly affect pods dry weight under the studied conditions.

Irrigation intervals significantly affected 100 seeds weight of snap bean , where, 8,12 , and 16 days interval treatment means were $91.5,85.6$ and $83.9 \%$ of that obtained with 4 days interval treatment mean. Both irrigation quantities and irrigation interval-irrigation quantities interaction treatments did not prove any significant effect on 100 seeds dry weight .

The highest seed yield resulted from irrigation interval of 4 days treatment, $1.0 \mathrm{Ep}$ treatment and from 4 days interval + 1.0 EP

Raising irrigation interval from 4 to 16 days decreased W.Ut.E of snap bean by $45.8 \%$.

Irrigation interval of 8 days or above was unsuitable for snap bean plant under drip irrigation system, where, water utilization efficiency was decreased with increasing irrigation water quantities from 0.8 to $1.0 \mathrm{Ep}$, comparing to irrigation interval of 4 days.

Irrigation intervals-irrigation water quantities interaction significantly affected W.Ut.E of snap bean yield. The highest W.Ut.E values $\left(0.689 \mathrm{~kg} / \mathrm{m}^{3}\right)$ were recorded under the short period of irrigation intervals(4 days) with irrigation quantities expressed as $1.0 \mathrm{Ep}$.

\section{2-squash}

Irrigation interval treatments affected squash fruit length, the highest value ( 12.5 $\mathrm{cm}$ ) was obtained with the irrigation interval of 2 days. Squash fruit diameter took the adversely trend of fruit length, as affected by irrigation water interval under the study. Irrigation interval - irrigation water quantities interaction significantly affected
\end{abstract}


squash fruit diameter, where, the highest fruit diameter was obtained with 8 days interval + 0.8 Ep.

Irrigation intervals treatments had a highly significant effect on squash fruit yield, where, the highest yield ( $799.596 \mathrm{~kg} / \mathrm{fed}$ ). Was obtained with irrigation interval 2 days treatment.

Raising irrigation interval from 2 to 8 days decreased W.Ut.E of squash by $70.8 \%$. Increasing W.Ut.E with increasing the amount of applied water meaningfully that the applied water quantities for yield is not enough for better growth.

Irrigation intervals-irrigation water quantities interaction significantly affected W.Ut.E of squash yield. The highest W.Ut.E values $\left(1.582 \mathrm{~kg} / \mathrm{m}^{3}\right)$ were recorded under the short period of irrigation intervals (2 days) with irrigation quantities expressed as $1.0 \mathrm{Ep}$.

\section{INTRODUCTION}

As the Egypt's population continues to increase, the crop water use efficiency should be increased. Vegetable crops require more water and more frequent irrigations than the most of agronomic crops. The total volume of water supplied to meet crop needs is influenced by water delivery systems and cultural practices. So, timing of each watering event plays a vital role on effective farm irrigation.

The main objective of the present study was to determine the effect of irrigation scheduling i.e. different irrigation intervals and the volume of water applied on snap bean and squash crops under drip irrigation system.

\section{MATERIALS AND METHODS}

Two field experiments were performed in summer and autumn seasons of 2004 at Sakha Agricultural Research Station, Kafr El-sheikh Governorate, North Nile Delta region, to find out the impact of irrigation intervals and amount of water applied under drip irrigation, on snap bean (Phaseolus vulgaris) and squash (Cucurbita pepo L.) production as well as their water relations.

The experimental soil was heavy in texture (59.6\% clay), having $\mathrm{pH}$ value of 7.8 in soil paste and EC value of $1.87 \mathrm{dSm}^{-1}$ in soil paste extract. The experimental field was ploughed twice by using chisel plough. A disk harrow was although used to find out a suitable seed-bed with good aggregates sizes and then, the soil was leveled.

Climatic data were obtained from Sakha Agro-meteorological Station.

The drip irrigation system which installed in the experimental field was evaluated through a practical approach which includes manufacturing coefficient of variation, uniformity coefficient percent, distribution uniformity percent and emitter flow rate variation. Values of these parameters refer to the good status of used drip irrigation system, according to ASAE measure (1998).

Two vegetable crops were cultivated, snap bean (var. Nebraska) as a spring crop and squash (var. Eskandrani)as a summer crop. Both were sown manually, on $30^{\text {th }}$ March and $27^{\text {th }}$ June 2004 , respectively. Sowing was done 
in each with planting space of $0.5 \times 0.8 \mathrm{~m}$. Irrigation water treatments were started at the complete emergence and stopped at $16^{\text {th }}$ June and $4^{\text {th }}$ September for snap bean and squash, respectively. N, P, and K fertilizers were applied as recommended.

Four irrigation intervals $(4,8,12,16$ days for snap bean, where the intervals were 2, 4, 6, 8 days for Squash)and two levels of Irrigation quantities ( 0.8 and $1.0 \mathrm{Ep}$ ) were assessed in this study. The treatments were arranged in split plot design with four replicates.

Yield parameters of snap bean such as pod length, pod diameter, Number of pods per plant ,Pods dry weight, weight of 100 seeds and total seed yield $(\mathrm{kg} / \mathrm{Fed}$.) were measured or determined. Yield parameters of squash such as fruit diameter $(\mathrm{cm})$ and fruit length $(\mathrm{cm})$ were also measured in addition to marketable immature were picked several times by hand, then weighed (kg/Fed.).

Water utilization efficiency was calculated according to Doorenbos and Pruitt (1975) as follow:

$$
\text { W.Ut.E. }=\frac{\text { Yield }(\mathrm{kg} / \mathrm{fed} .)}{\text { Irrigation water applied }\left(\mathrm{m}^{3} / \text { fed } .\right)}
$$

The collected data were subjected to the statistical analysis, using the analysis of variance (ANOVA). The Duncan's multiple range test was used to compare between the means.

\section{1-Snap Bean}

\section{RESULTS AND DISSCUTION}

Data of Table 1 show pod length $(\mathrm{cm})$ of snap bean as affected by irrigation interval, irrigation water quantities and their interaction. No significant differences were found between the studied treatment means, while the highest value was obtained with the treatment of irrigation interval of 4 days with irrigation water quantity of $1.0 \mathrm{Ep}$, meanwhile the lowest value was obtained with the treatment of 16 days interval with irrigation water quantity of $0.8 \mathrm{Ep}$. The highest diameter $(1.1 \mathrm{~cm})$ was obtained under 12 days interval and 1.0 Ep.

Table (1) : Pod length $(\mathrm{cm})$ of snap bean as affected by irrigation treatments.

\begin{tabular}{cccc}
\hline \multirow{2}{*}{$\begin{array}{c}\text { Irrigation } \\
\text { intervals }\end{array}$} & \multicolumn{2}{c}{ Water applied } & \multirow{2}{*}{ Mean } \\
\cline { 2 - 3 } & $\mathbf{0 . 8} \mathbf{E p}$ & $\mathbf{1 . 0 ~ E p}$ & $\mathbf{9 . 2 5}$ \\
4 days & 8.80 & 9.70 & $\mathbf{8 . 9 5}$ \\
8days & 8.80 & 9.10 & $\mathbf{8 . 9 5}$ \\
12days & 8.90 & 9.00 & $\mathbf{8 . 5 0}$ \\
16days & 850 & 8.50 & \\
\hline Mean & $\mathbf{8 . 7 5}$ & $\mathbf{9 . 1}$ & N.S
\end{tabular}


Data of Table 2 reveal that irrigation water quantities significantly affected pod diameter of snap bean plant. The lowest value was obtained with the treatments of 16 days interval, with irrigation water quantity of 0.8 $\mathrm{Ep}$ (the longest interval with the lowest quantity of irrigation water).

Table (2): Pod diameter $(\mathrm{cm})$ of snap bean as affected by irrigation treatments.

\begin{tabular}{cccc}
\hline Irrigation & \multicolumn{2}{c}{ Water applied } & \multirow{2}{*}{ Mean } \\
\cline { 2 - 3 } intervals & $\mathbf{0 . 8} \mathrm{Ep}$ & $\mathbf{1 . 0 ~ E p}$ & \\
\hline 4 days & $1.00 \mathrm{ab}$ & $0.98 \mathrm{ab}$ & $\mathbf{0 . 9 9}$ \\
8days & $0.99 \mathrm{ab}$ & $1.06 \mathrm{ab}$ & $\mathbf{1 . 0 3}$ \\
12days & $0.99 \mathrm{ab}$ & $1.10 \mathrm{a}$ & $\mathbf{1 . 0 5}$ \\
16days & $0.95 \mathrm{~b}$ & 0.98 & $\mathbf{0 . 9 7}$ \\
\hline Mean & $\mathbf{0 . 9 8}$ & $\mathbf{1 . 0 3}$ & \\
\hline Irrigation intervals & N.S & $; \quad$ Water quantities ${ }^{\text {* }} ; \quad$ Interaction & N.S
\end{tabular}

Data of Table 3 reveal that irrigation water intervals significantly affected number of pods/plant, where 4 days interval recorded the highest mean (9.7). No significant differences were found between irrigation water quantities treatment means in this trait. These results are in contradictory with that of Fekadu (2002), who found that Pod number per snap bean plant was increased by $28 \%$ and $48 \%$ due to 0.75 and 1.00 pan respectively, compared with the 0.25 pan treatment.

The highest value (10.7 which was obtained with the treatment of 4 days interval, with irrigation water quantity of $1.0 \mathrm{Ep}$ ) represents $150.7 \%$ of the lowest value(7.1 which was obtained with the treatment of 12 days interval with the irrigation water quantity of $1.0 \mathrm{Ep}$ ).

Table (3): Number of pods/plant of snap bean as affected by irrigation treatments.

\begin{tabular}{|c|c|c|c|}
\hline \multirow{2}{*}{$\begin{array}{l}\text { Irrigation } \\
\text { intervals }\end{array}$} & \multicolumn{2}{|c|}{ Water applied } & \multirow[b]{2}{*}{ Mean } \\
\hline & $0.8 \mathrm{Ep}$ & $1.0 \mathrm{Ep}$ & \\
\hline 4 days & 8.70 & 10.70 & $9.70 \mathrm{a}$ \\
\hline 8 days & 9.70 & 7.90 & $8.80 a b$ \\
\hline 12 days & 7.40 & 7.60 & $7.40 \mathrm{~b}$ \\
\hline 16 days & 7.10 & 7.10 & $7.10 a b$ \\
\hline Mean & 8.2 & 8.3 & \\
\hline
\end{tabular}

As presented in Table 4, irrigation intervals significantly affected pods dry weight/plant, where 4 days interval treatment mean represent $157.5 \%$ of that of 16 days interval treatment mean. Irrigation water quantities didn't significantly affect pods dry weight under the studied conditions.

Data of that Table pointed out also that raising the irrigation water quantity from $0.8 \mathrm{Ep}$ to $1.0 \mathrm{Ep}$ with 4 days interval, increased plant pods weight by $36.9 \%$, while the same raising in irrigation water quantity decreased the same trait by $11.5,20.9 \%$ and $9.4 \%$ with 8,12 and 16 days interval, respectively. 
Table (4): Weight of dry pods (gm/plant) of snap bean as affected by irrigation treatments.

\begin{tabular}{cccc}
\hline Irrigation & \multicolumn{2}{c}{ Water applied } & \multirow{2}{*}{ Mean } \\
\cline { 2 - 3 } intervals & $\mathbf{0 . 8 ~ E p}$ & $\mathbf{1 . 0 ~ E p}$ & \\
\hline 4 days & $16.00 \mathrm{~b}$ & $21.90 \mathrm{a}$ & $\mathbf{1 8 . 9 5 ~ \mathbf { ~ }}$ \\
8days & $15.60 \mathrm{~b}$ & $13.80 \mathrm{bc}$ & $\mathbf{1 4 . 7 0 ~ a b}$ \\
12days & $13.80 \mathrm{bc}$ & $12.50 \mathrm{bc}$ & $\mathbf{1 3 . 1 5 b}$ \\
16days & $13.40 \mathrm{bc}$ & $10.60 \mathrm{C}$ & $\mathbf{1 2 . 0 0 ~ \mathbf { ~ }}$ \\
\hline Mean & $\mathbf{1 4 . 7}$ & $\mathbf{1 4 . 7}$ & \\
\hline Irrigation intervals $^{*} ;$ & Water quantities & $\mathbf{N . S} ; \quad$ Interaction ${ }^{* *}$
\end{tabular}

Data of Table 5 reveal that irrigation intervals negatively and significantly affected 100 seeds weight of snap bean, where, 8,12 , and 16 days interval treatment means were $91.5,85.6$ and $83.9 \%$ of that obtained with 4 days interval treatment.

Both irrigation quantities and irrigation interval-irrigation quantities interaction treatments, did not prove any significant effect on 100 seeds dry weight of snap bean. Data also reveal that the treatment of 4 days interval, with irrigation water quantity of $1.0 \mathrm{Ep}$ achieved the highest value of 100 seeds weight $(45.1 \mathrm{gm})$. The lowest value of this trait $(36.1 \mathrm{gm})$ was obtained with the treatment of 16 days interval with irrigation water quantity of $0.8 \mathrm{Ep}$.

Table (5): 100 seeds dry Weight (gm) of snap bean as affected by irrigation treatments.

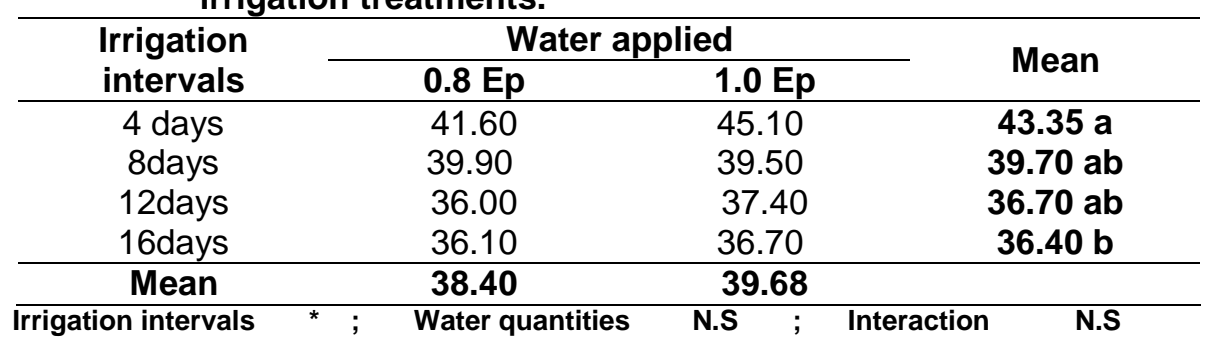

Data in Table 6 reveal that dry seeds yield was significantly influenced by irrigation intervals. The highest seed yield $(338.023 \mathrm{~kg} / \mathrm{fed})$ resulted from irrigation interval of 4 days treatment, while, the lowest seed yield (182.987 $\mathrm{kg} / \mathrm{fed}$ ) was obtained from irrigation interval of 16 days treatment $(45.9 \%$ decrease). These results are in agreement with that of Boutraa and Sanders (2001). They reported that water use efficiencies for bean [Phaseolus vulgaris] were reduced by water stress.

Regarding the amount of water applied, there were highly significant differences between water level treatment means. The highest value 253.18 $\mathrm{kg} / \mathrm{fed}$. was obtained from $1.0 \mathrm{Ep}$ treatment. while, the lowest seed yield $218.598 \mathrm{~kg} / \mathrm{fed}$. was obtained from $0.8 \mathrm{Ep}$ treatment. These results are in contradictory with that of Gajendra-Singh and Singh (1999). They outlined that French bean yield was increased with increasing irrigation rate up to a plateau at $0.75 \mathrm{IW}: \mathrm{CPE}$ ( Irrigation water : cumulative pan evaporation ). 
The interaction between irrigation interval and amount of applied water, significantly affected snap bean seed yield as it is clear in Table 6, where the highest $(403.212 \mathrm{Kg} / \mathrm{Fed}$.) and the lowest $(182.968 \mathrm{Kg} / \mathrm{Fed}$.) values were obtained under the treatments of 4 days interval $+1.0 \mathrm{EP}$ and 16 days interval + 0.8 EP, respectively .

Table (6):Dry seed yield (kg/fed.)of snap bean as affected by irrigation treatments.

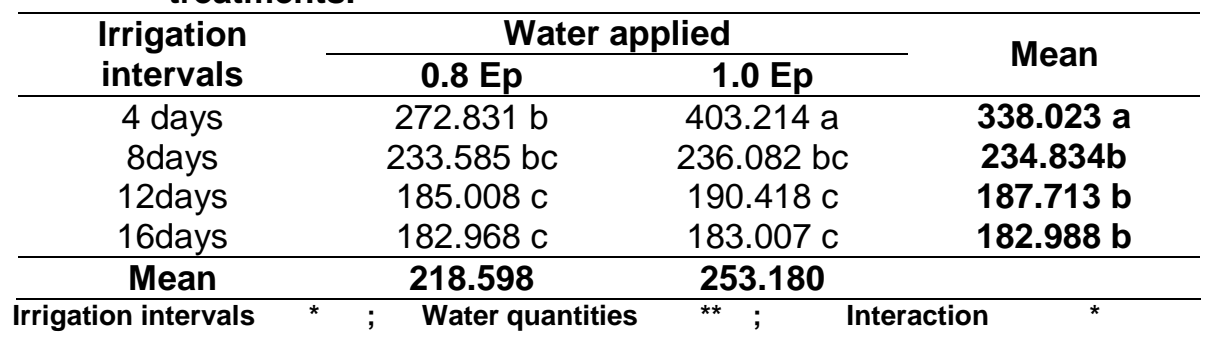

Water utilization efficiency (W.Ut.E) of snap bean as affected by the studied irrigation intervals, irrigation water quantities (0.8 and $1.0 \mathrm{Ep})$ and their interaction were tabulated in Table 7.

Raising irrigation interval from 4 to 16 days decreased W.Ut.E of snap bean by $45.8 \%$.

W.ut.E values were increased from 0.404 to $0.432 \mathrm{~kg} / \mathrm{m}^{3}$ for snap bean by increasing irrigation water applied quantities from 0.8 to $1.0 \mathrm{Ep}$. This trend (increasing w.ut.E with increasing the amount of applied water) meaningfully, that the applied water quantities for snap bean crop was not enough for better growth.

Irrigation intervals-irrigation water quantities interaction, significantly affected W.Ut.E of snap bea yield. The highest W.Ut.E values $\left(0.689 \mathrm{~kg} / \mathrm{m}^{3}\right.$ for snap bean) was recorded under the short period of irrigation intervals (4 days) with irrigation quantities, expressed as 1.0Ep. These results are in agreement with that of Mahlooji et al. (2000) They stated that water use efficiency for snap bean seed yield were $0.557,0.556$ and $0.329 \mathrm{~kg} / \mathrm{m} 3$, for irrigation treatment of irrigation after 50,70 and $90 \mathrm{~mm}$ evaporation from class A pan , respectively. irrigation regime.

Table (7): Water utilization efficiency values (W.Ut.E) $\mathrm{kg} / \mathrm{m}^{3}$ of snap bean.

\begin{tabular}{|c|c|c|c|}
\hline \multirow{2}{*}{$\begin{array}{l}\text { Irrigation } \\
\text { intervals }\end{array}$} & \multicolumn{2}{|c|}{ Water applied } & \multirow{2}{*}{ Mean } \\
\hline & $0.8 \mathrm{Ep}$ & $1.0 \mathrm{Ep}$ & \\
\hline 4 days & $0.511 \mathrm{~b}$ & $0.689 \mathrm{a}$ & $0.600 a$ \\
\hline 8 days & $0.430 \mathrm{c}$ & $0.403 \mathrm{~b}$ & $0.417 \mathrm{~b}$ \\
\hline 12 days & $0.338 d$ & $0.323 d$ & $0.331 \mathrm{c}$ \\
\hline 16 days & $0.337 d$ & $0.313 \mathrm{e}$ & $0.325 \mathrm{c}$ \\
\hline Mean & $0.404 \mathrm{~b}$ & $0.432 \mathrm{a}$ & \\
\hline
\end{tabular}


Data of Table 7 reveal that irrigation interval of 8 days or above is unsuitable for snap bean plant under drip irrigation system, where, water utilization efficiency was decreased with increasing irrigation water quantities from 0.8 to $1.0 \mathrm{Ep}$, comparing to irrigation interval of 4 days.

\section{2- Squash}

Data of Table 8 show squash fruit length as affected by the studied treatments. A significant effect was found due to appling the irrigation interval treatments. The highest value of Fruit length $(12.5 \mathrm{~cm})$ was obtained with the irrigation interval of 2 days, meanwhile, the lowest value $(10.0 \mathrm{~cm})$ was resulted from irrigation interval treatment of 8 days.

Regarding water quantities treatments, the higher value $(11.53 \mathrm{~cm})$ was obtained with 1.0 Ep. While, the lower value $(10.90 \mathrm{~cm})$ was recorded with $1.0 \mathrm{Ep}$ treatment. Significant effect on fruit length was resulted from the interaction between irrigation intervals and irrigation water quantities, where, raising irrigation interval within each irrigation quantity level decreased squash fruit length.

Table (8): Fruit length $(\mathrm{cm})$ of squash as affected by irrigation treatments.

\begin{tabular}{|c|c|c|c|}
\hline \multirow{2}{*}{$\begin{array}{l}\text { Irrigation } \\
\text { intervals }\end{array}$} & \multicolumn{2}{|c|}{ Water applied } & \multirow{2}{*}{ Mean } \\
\hline & $0.8 \mathrm{Ep}$ & $1.0 \mathrm{Ep}$ & \\
\hline 2 days & $12.30 \mathrm{a}$ & $12.70 \mathrm{a}$ & $12.50 \mathrm{a}$ \\
\hline 4days & $10.70 \mathrm{a}$ & $12.60 \mathrm{~b}$ & $11.65 \mathrm{~b}$ \\
\hline 6days & $10.60 \mathrm{~b}$ & $10.80 \mathrm{~b}$ & $10.70 \mathrm{c}$ \\
\hline 8days & $10.00 \mathrm{~b}$ & $10.0 \mathrm{~b}$ & $10.00 \mathrm{c}$ \\
\hline Mean & 10.90 & 11.53 & \\
\hline
\end{tabular}

Data of Table (9) reveal that squash fruit diameter took the adversely trend of fruit length as affected by irrigation interval under the study, where the highest value $(4.42 \mathrm{~cm})$ was obtained with 8 days interval treatment.

Irrigation water quantities under the study didn't significantly affect squash fruit diameter. Appling irrigation water as 1.0 Ep increased the squash fruit diameter by $2.3 \%$ only.

Irrigation interval - irrigation water quantities interaction significantly affected squash fruit diameter, where the highest fruit diameter was obtained with 8 days interval $+0.8 \mathrm{Ep}$.

Table (9): Fruit diameter (cm) of squash as affected by irrigation treatments.

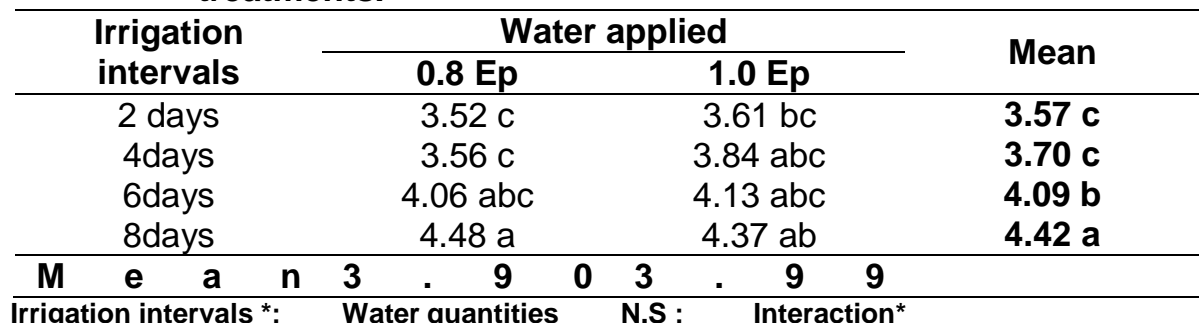


Data of Table (10) reveal that irrigation intervals treatments had a highly significant effect on fruit yield of squash. The highest yield of $799.596 \mathrm{~kg} / \mathrm{fed}$. Was obtained with irrigation interval of 2 days treatment. While, the lowest yield $(225.470 \mathrm{~kg} / \mathrm{fed}$.) was obtained with irrigation interval of 8 days treatment. Generally, yield was increased by decreasing irrigation interval. These results are in agreement with that of Dalton (2002) who decided that irrigation at $40 \%$ depletion treatment produced a two-fold increase in export yield of squash, using a $60 \%$ increase in water applied. The $80 \%$ depletion treatment yield was significantly lower than the control treatment.

Water quantities had also highly significant effects on squash fruit yield. The highest yield of $464.429 \mathrm{~kg} / \mathrm{fed}$. was obtained with $1.0 \mathrm{Ep}$ treatment. While the lowest yield $402793 \mathrm{~kg} / \mathrm{fed}$. was resulted from $0.8 \mathrm{Ep}$ treatment. The obtained results are in contradictory with that of Couto et al. (1999). They concluded That applied irrigation water through drip irrigation at three levels: approximately $80 \%, 100 \%$ (which was assumed to be optimal), and $125 \%$ of crop evapotranspiration (ETc) had no significant effect on squash yield.

Highly significant effect was found due to the interaction between the factors studied but the results are in contradictory with that of Ertek et al. (2004). they concluded that pan coefficient of 0.85 with 5 -days irrigation interval is recommended for summer squash grown under field conditions in order to get higher summer squash yield.

Table (10): Fruit yield (kg/fed.) of squash as affected by irrigation water treatments.

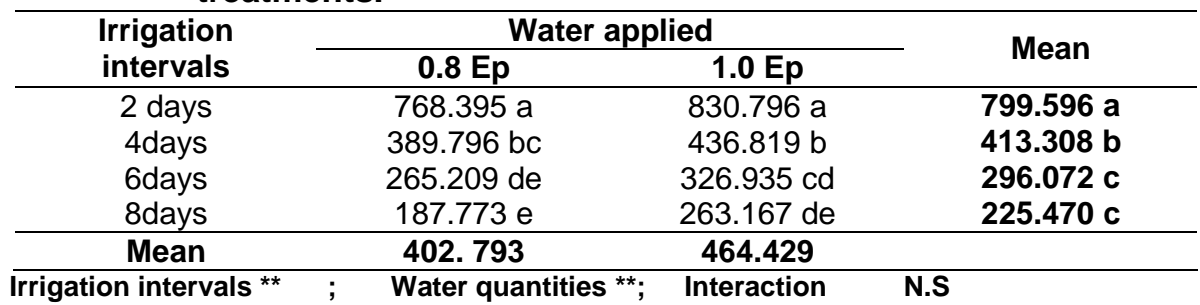

Water utilization efficiency (W.Ut.E) of squash plants as affected by the studied irrigation intervals, irrigation water quantities (0.8 and $1.0 \mathrm{Ep})$ and their interaction were tabulated in Table 11.

Raising irrigation interval from 2 to 8 days decreased W.Ut.E of squash by $70.8 \%$.

W.ut.E values were increased from from 0.837 to $0.887 \mathrm{~kg} / \mathrm{m}^{3}$ for squash by increasing irrigation water applied quantities from 0.8 to $1.0 \mathrm{Ep}$. These results are in agreement with that of Al-Omran et al. (2005). They outlined that water use efficiency (WUE) values of squash crop were increased as linearly with applied water via micro-irrigation system, and decreased at the highest irrigation level (120\% of reference pan evaporation ; ETo).

Irrigation intervals-irrigation water quantities interaction, significantly affected W.Ut.E of squash yield. The highest W.Ut.E values $(1.528 \mathrm{Kg} / \mathrm{m} 3$ for squash) were recorded under the short period of irrigation intervals for each(2 days) with irrigation quantities, expressed as 1.0Ep. 
Table (11): Water utilization efficiency values (W.Ut.E) $\mathrm{kg} / \mathrm{m}^{3}$ of squash.

\begin{tabular}{cccc}
\hline \multirow{2}{*}{$\begin{array}{c}\text { Irrigation } \\
\text { intervals }\end{array}$} & \multicolumn{2}{c}{ Water applied } & \multirow{2}{*}{ Mean } \\
\cline { 2 - 3 } 2 days & $\mathbf{0 . 8 \mathrm { Ep }}$ & $\mathbf{1 . 0 \mathrm { Ep }}$ & \\
\hline 4days & $1.574 \mathrm{a}$ & $1.582 \mathrm{a}$ & $\mathbf{1 . 5 7 8 ~ \mathbf { ~ a }}$ \\
6days & $0.800 \mathrm{~b}$ & $0.819 \mathrm{~b}$ & $\mathbf{0 . 8 1 0 ~ b}$ \\
8days & $0.561 \mathrm{~d}$ & $0.638 \mathrm{c}$ & $\mathbf{0 . 6 0 0 ~ b}$ \\
\hline Mean & $0.403 \mathrm{e}$ & $0.518 \mathrm{~d}$ & $\mathbf{0 . 4 6 1} \mathbf{~}$ \\
\hline
\end{tabular}

Irrigation intervals ${ }^{* \star} \quad$ Water quantities ${ }^{* *}$ Interaction ${ }^{* \star}$

It should be noted that, for complete evaluation of different treatments under the study, the total yield should be taken into consideration beside W.Ut.E value.

\section{REFERENCES}

Al-Omran, A. M.; A. S. Sheta;, A. M. Falata; A. Al-Harbi,(2005). Effect of drip irrigation on squash (Cucurbita pepo) yield and water use efficiency in sandy calcareous soils amended with clay deposits. Agricultural-WaterManagement. 73(1): 43-55.

ASAE standards,(1998 a). Design installation and performance of trickle irrigation systems. 45th Ed, s 526.1,st. Joseph ,Mich , ASAE.

Boutraa, T. and F. E. Sanders (2001). Effects of interactions of moisture regime and nutrient addition on nodulation and carbon partitioning in two cultivars of bean (Phaseolus vulgaris L.). Journal of Agronomy and Crop Science. 186(4): 229-237.

Couto, L.; Haman, D. Z.; Hochmuth, G. J.; Smajstrla, A. G. (1999). Nitrogen and irrigation management for squash production in North Florida. Proceedings of the Florida State Horticultural Society. 1999 publ 2000; (112): 329-332.

Dalton, J. A. (2002). Scheduling for improved yield using volumetric moisture content. Food production, poverty alleviation and environmental challenges as influenced-by limited water resources and population growth Volume 1A 18th International Congress on Irrigation and Drainage, Montreal, Canada, 2002. 2002; 1-16.

Doorenbos, J. and W. O. Pruitt.(1975). Guidelines for predicting crop water requirements. Irrigation and Drainage paper,FAO, Rome,No.24pp. 144.

Ertek,-A; S. Sensoy; C. Kucukyumuk; I. Gedik (2004). Irrigation frequency and amount affect yield components of summer squash (Cucurbita pepo L.). Agricultural Water Management. 67(1): 63-76.

Fekadu, Y. (2002). Irrigation scheduling by pan evaporation for furrow irrigated haricot bean at Dire Dawa, Ethiopia. Landnutzung und Landentwicklung.43(3): 135-139.

Gajendra-Singh and T. P. Singh (1999). Effect of moisture regimes and fertility levels on growth, yield and water use of French bean (Phaseolus vulgaris). Indian Journal of Agronomy. 44(2): 389-391.

Mahlooji, M.; Mousavi, S. F.; Karimi, M. (2000). The effects of water stress and planting date on yield and yield components of pinto bean (Phaseolus vulgaris) Journal of Science and Technology of Agriculture and Natural Resources. 4(1): 57-68. 
Labeeb, G. et al.

جدولة ري الفاصوليا والكوسة تحت نظام الري بالتنقيط بمنطقة شمال دلتا النيل

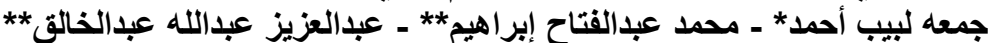

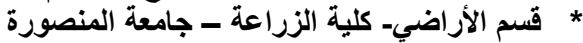
* * معه بحوث الأراضي واضلية الزراعة والبيئة

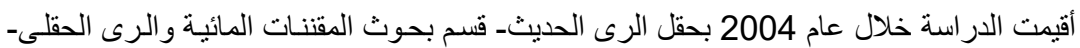

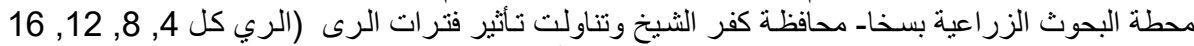

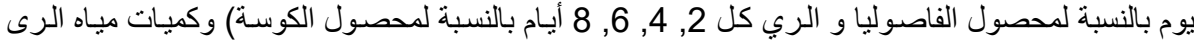

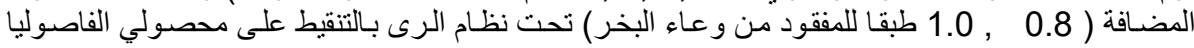

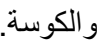

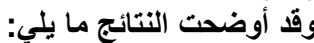

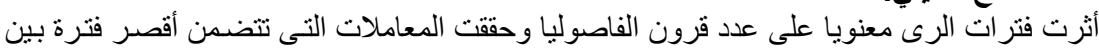

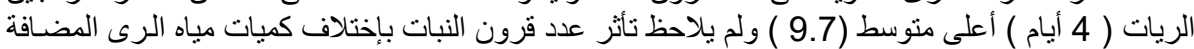

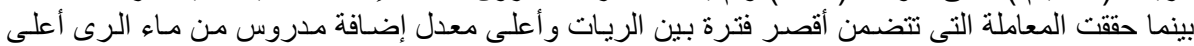

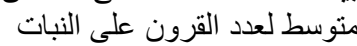

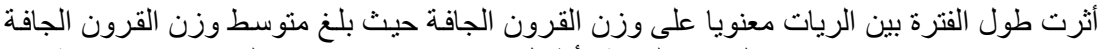

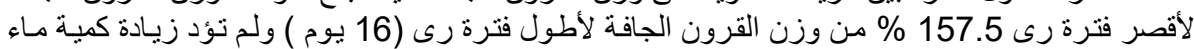

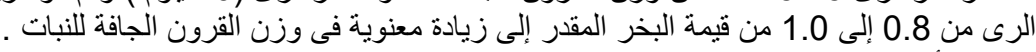

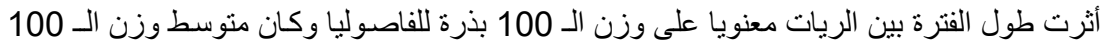

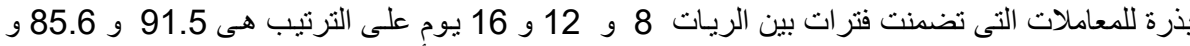

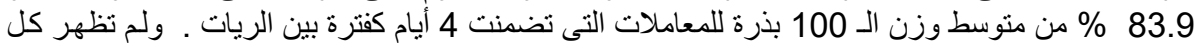

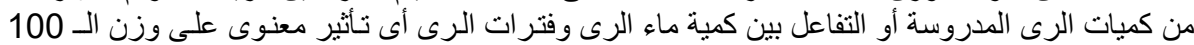

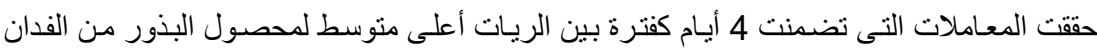

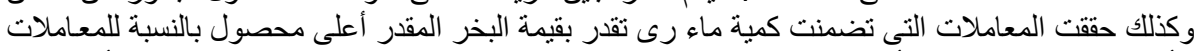

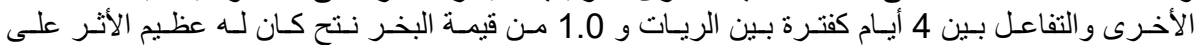

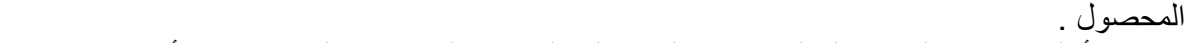

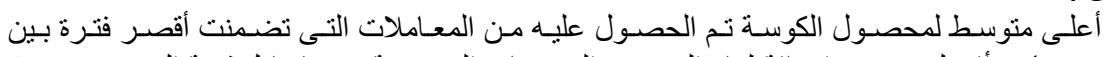
الريات(يومين ) و أفضل مستوى إضافة لماء الرى من المستوليات المدروسة هو مايعادل قيمة البخر نتح حيث

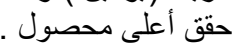
زيـادة الفتـرة بين الريـات لمحصـول الفاصـوليا الـى 8 أيسام أو أكثر أدى إلىى نقص كفـاءة استخدام

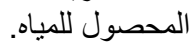

زيادة الفترة بين الريات من 4 إلى 16 يوم أدت إلى نقص كفاءة إبتخدام محصول الفاصوليا للمياه

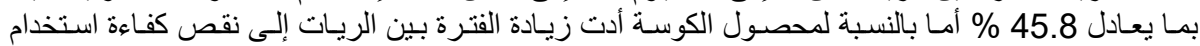

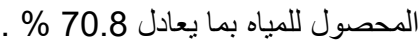

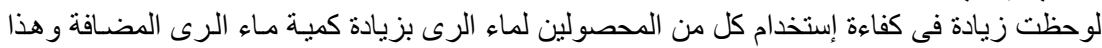

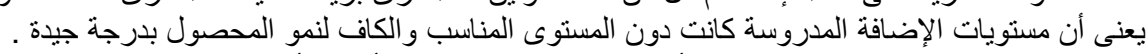

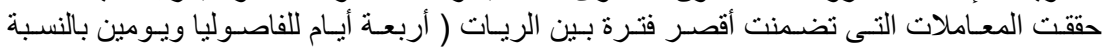

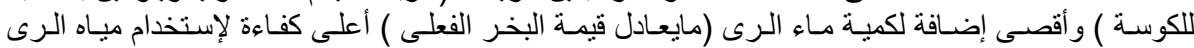
( 0.689 كجم/م 3 للفاصوليا و 1.582 كجم / م 3 للكوسة إنساءة). التوصيات

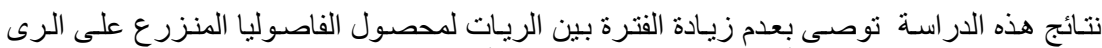
بالتنقيط تحت ظروف منطقة الدراسة أو المناطق المشابهة عن 4 أيام وللكوسة بلثة عن يومين إذ لم تزد كمية مياه

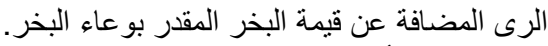

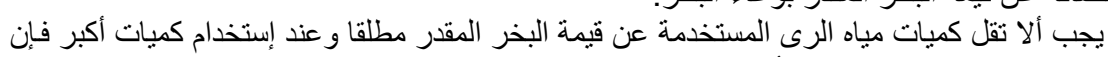
ذللك قد يسمح بإطالة فترة الرى عن 4 أيام ويومين للفاصوليا والكوسة الكئل على الترتيب. 